\title{
Mizoroki-Heck cross-couplings of 2-acetyl-5-bromobenzofuran and aryl halides under microwave irradiation
}

\author{
Mohamed R. Shaaban,, ${ }^{\text {a,b }}$ Ahmed F. Darweesh, ${ }^{a}$ Kamal M. Dawood ${ }^{\mathrm{a}, *}$ \\ and Ahmad M. Farag \\ ${ }^{a}$ Department of Chemistry, Faculty of Science, Cairo University, Giza 12613, Egypt \\ ${ }^{b}$ Department of Chemistry, Faculty of Applied Science, Umm Al-Qura University, \\ Makkah Almukarramah, Saudi Arabia \\ E-mail: dr_dawood@yahoo.com
}

\begin{abstract}
Mizoroki-Heck cross-coupling reactions of 2-acetyl-5-bromobenzofuran as well as activated and deactivated aryl bromides with various olefins were investigated under both thermal as well as microwave irradiating conditions in open air using water solvent.
\end{abstract}

Keywords: Palladium, catalysis, microwave, cross coupling reactions, benzofurans, aryl halides

\section{Introduction}

Palladium-catalyzed cross-coupling reactions leading to the formation of carbon-carbon bonds are among the most powerful transformations in organic synthesis. ${ }^{1,2}$ Mizoroki-Heck crosscoupling reaction is a powerful and widely used method to couple aryl halides with terminal olefins to form cinnamates and stilbenes which are of industrial importance. ${ }^{3}$ The possibility of carrying out Mizoroki-Heck cross-coupling reactions in water and under open air could be of great interest for the development of industrial processes. ${ }^{4,5}$ One of the challenges that are facing organic chemists now is focused on the design of new methodologies able to make the already known chemical transformations simpler, faster, cheaper, and in general, more efficient processes. In particular, increasing attention has been paid to the 'green chemistry' of these processes; this concept being understood as a set of principles ${ }^{6}$ that reduce or eliminate the use or generation of hazardous substances. ${ }^{7,8}$ Furthermore, microwave irradiation methodology assists in achieving rapid incorporation of organic synthesis into broad research diversities. ${ }^{9,10}$

Intense efforts have been made directed towards the synthesis of benzofuran derivatives due to their biological and pharmacological properties, ${ }^{11,12}$ and to their natural occurrence. ${ }^{13,14}$ In continuation of our recent research work directed to the use of Pd (II)-complexes as precatalysts in $\mathrm{C}-\mathrm{C}$ cross couplings in aqueous media, ${ }^{15,16}$ we study here the catalytic reactivity of the $\mathrm{Pd}(\mathrm{II})$ - 
complex ${ }^{17} 3$ in the Mizoroki-Heck cross coupling reactions of 2-acetyl-5-bromobenzofuran as well as aryl and pyridyl halides with a variety of terminal olefins under thermal as well as microwave irradiating conditions. To the best of our knowledge, these are the first Heck vinylation reactions of 2-acetyl-5-bromobenzofuran.

\section{Results and Discussion}

\section{Heck cross-coupling reactions of aryl halides}

At the beginning, the effect of concentration of the Pd-complex $\mathbf{3}$ on the Heck cross-coupling between styrene 2 and $p$-bromoacetophenone 1 under thermal heating condition was evaluated. The coupling reaction was conducted in DMF $(3 \mathrm{~mL})$ at $130{ }^{\circ} \mathrm{C}$ for $90 \mathrm{~min}$ using different concentrations of the precatalyst $\mathbf{3}$ and in all cases the molar ratios of $p$-bromoacetophenone $\mathbf{1}$ / styrene 2/ TBAB/ $\mathrm{Et}_{3} \mathrm{~N}$ : 1/ 1.5/ 0.6/3. Therefore, use of $1 \mathrm{~mol} \%$ of the complex 3 resulted in full conversion into 4-acetylstilbene $\mathbf{4}$ in $96 \%$ isolated yield. The reaction was repeated with different catalytic concentrations; $0.75,0.5,0.25,0.125,0.05,0.025,0.0125$ and $0.0 \mathrm{~mol} \%$ of complex 3 with respect to $p$-bromoacetophenone 1. Full conversions were obtained at concentrations; 0.75 , $0.5,0.25$ and $0.125 \mathrm{~mol} \%$ of the complex 3 with turnover numbers (TON) 133, 200, 400 and 800 respectively. The reaction was again repeated using $0.05,0.025$ and $0.0125 \mathrm{~mol} \%$ of the complex 3 giving 4-acetylstilbene 4 in 93, 67 and $13 \%$ GC-conversions with TON 1860, 2680 and 1000, respectively. These results reveal the high activity of the catalytic system that is used in this Heck cross-coupling reaction. Finally, the starting substrates were completely recovered unchanged in the absence of the precatalyst 3 .

Pd-complexes are reported to serve as "dormant species" that are not involved in the real catalytic cycle but are a source of a catalytically active species of unknown nature. Therefore, the $\operatorname{Pd}(\mathrm{II})$-complex 3 may serve here as a reservoir that is not involved in the real catalytic cycle but is a source of release a considerable amount of colloidal $\operatorname{Pd}(0)$ which can show catalytic activity at low concentrations. De Vries and co-workers noted for Heck reactions that low concentrations of $\operatorname{Pd}(0)$ in solution will aggregate and deactivate much more slowly than high concentrations. ${ }^{18}$ In order to prevent deactivation (precipitation of palladium black) of these active species at higher reaction temperatures, it is necessary to add activating agents such as TBAB to the reaction mixture which has a beneficial effect in Heck reactions due to the ability of TBAB to stabilize $\operatorname{Pd}(0)$ nanoparticles against further aggregation and deactivation. ${ }^{19}$ The study of TONs in palladium-mediated $\mathrm{C}-\mathrm{C}$ bond formation processes is a very important area of research and any catalyst displaying $>10^{3}$ turnover number is defined as high turnover catalyst (HTC). ${ }^{20}$ Therefore, Pd-complex $\mathbf{3}$ can be considered as high turn over catalyst.

Next, the catalytic activity of the Pd(II) complex 3 towards Heck cross-coupling reaction of $p$-bromoacetophenone with styrene in different solvents (water, DMF or toluene) and different bases $\left(\mathrm{KOH}, \mathrm{K}_{2} \mathrm{CO}_{3}\right.$ or $\mathrm{Et}_{3} \mathrm{~N}$ ) using $0.25 \mathrm{~mol} \%$ under thermal heating was examined. Among the solvents tested, water as an eco-friendly solvent provided full conversion ( $85 \%$ isolated yield), in 
the presence of $\mathrm{KOH}$ as base and $\mathrm{TBAB}$ as additive, after $90 \mathrm{~min}$ of thermal heating at $100{ }^{\circ} \mathrm{C}$ (entry 1, Table 1). Under this condition, using $\mathrm{K}_{2} \mathrm{CO}_{3}$ and $\mathrm{Et}_{3} \mathrm{~N}$ as bases gave 90 and 45\% GCconversions, respectively (entries 3 and 4, Table 1). When the reaction was performed in $\mathrm{DMF} / \mathrm{Et}_{3} \mathrm{~N} / \mathrm{TBAB}$ at reflux temperature for $90 \mathrm{~min}$, full conversion with $92 \%$ isolated yield was obtained. No coupling product was detected when the last catalytic system was applied at r.t. for 24h. Using DMF as solvent with $\mathrm{KOH}$ as base in the presence of TBAB resulted in $89 \%$ GCconversion into 4-acetylstilbene 4 (entry 5, Table 1). Toluene was not a suitable solvent for this reaction regardless the used base (entries 9-11, Table 1). The TLC and ${ }^{1} \mathrm{H}$ NMR spectrum of the crude reaction product 4 , were more clear and less contaminated with by-products when DMF was the reaction solvent (run 6, Table 1) than when water was used as a solvent (run 1, Table 1), in addition to the higher isolated yield (92\%) after run 6 comparing to that obtained after run 1 $(85 \%)$. Therefore, DMF was the proper solvent for this reaction. The catalytic system $\left(\mathrm{DMF} / \mathrm{TBAB} / \mathrm{Et}_{3} \mathrm{~N}\right)$ was applied for the same cross coupling reaction under microwave irradiation instead of thermal heating and the reaction was completed within 5 min to give 4 in $88 \%$ yield.

Table 1. Effect of base and solvent on Heck coupling of p-bromoacetophenone with styrene

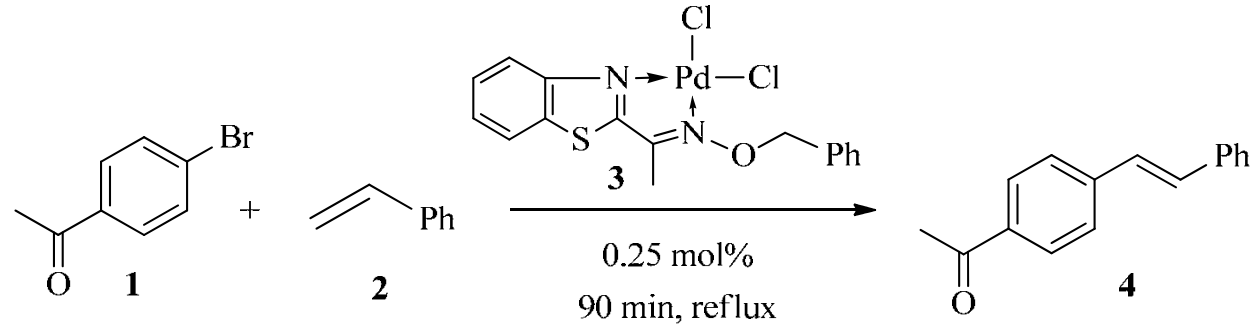

\begin{tabular}{cccc}
\hline Entry & Solvent & Base & Yield\% ${ }^{\mathrm{a}, \mathrm{b}}$ \\
\hline 1 & $\mathrm{H}_{2} \mathrm{O} / \mathrm{TBAB}$ & $\mathrm{KOH}$ & $100(85)$ \\
2 & $\mathrm{H}_{2} \mathrm{O}$ & $\mathrm{KOH}$ & $85(80)$ \\
3 & $\mathrm{H}_{2} \mathrm{O} / \mathrm{TBAB}$ & $\mathrm{K}_{2} \mathrm{CO}_{3}$ & $90(78)$ \\
4 & $\mathrm{H}_{2} \mathrm{O} / \mathrm{TBAB}$ & $\mathrm{Et}_{3} \mathrm{~N}$ & 45 \\
5 & $\mathrm{DMF} / \mathrm{TBAB}$ & $\mathrm{KOH}$ & 89 \\
6 & $\mathrm{DMF} / \mathrm{TBAB}$ & $\mathrm{Et}_{3} \mathrm{~N}$ & $100(92)^{\mathrm{c}, \mathrm{d}}$ \\
7 & DMF & $\mathrm{Et}_{3} \mathrm{~N}$ & $99(89)$ \\
8 & $\mathrm{DMF} / \mathrm{TBAB}$ & $\mathrm{K}_{2} \mathrm{CO}_{3}$ & 97 \\
9 & Toluene & $\mathrm{KOH}$ & 0 \\
10 & Toluene & $\mathrm{Et}_{3} \mathrm{~N}$ & 11 \\
11 & Toluene & $\mathrm{K}_{2} \mathrm{CO}_{3}$ & 22 \\
\hline
\end{tabular}

${ }^{\mathrm{a} C}$ Conditions: $p$-Bromoacetophenone: $1 \mathrm{mmol}$; styrene: $1.5 \mathrm{mmol}$; TBAB: $0.6 \mathrm{mmol}$; base: $3 \mathrm{mmol}$; solvent: $3 \mathrm{~mL}$, Pd-complex: $0.25 \mathrm{~mol} \%$ at reflux condition for $90 \mathrm{~min}$. ${ }^{\mathrm{b}}$ Conversions 
were based on $\mathrm{GC}$-analysis and the values in parentheses refer to the isolated yields. ${ }^{\mathrm{c}}$ Repeating this condition at r.t. for $24 \mathrm{~h}$ resulted in no reaction based on GC-analysis. ${ }^{\mathrm{d}}$ Repeating this condition under microwave heating $(250 \mathrm{Watt})$ at $160{ }^{\circ} \mathrm{C}$ for $5 \mathrm{~min}$ resulted full conversion with $88 \%$ isolated yield after $5 \mathrm{~min}$.

The optimized catalytic condition using $\mathrm{DMF} / \mathrm{TBAB} / \mathrm{Et}_{3} \mathrm{~N}$ under microwave irradiation was applied for carrying out Mizoroki-Heck reactions of activated and deactivated aryl bromides 1, 5 and 6 with various olefins 2a-d as outlined in Table 2. Thus, microwave-assisted Heck crosscoupling of the aryl bromides 1, 5 and $\mathbf{6}$ with styrene 2a resulted in full conversion into the corresponding stilbenes 4, 17 and 21 in very good isolated yields (entries 1, 5 and 9, Table 2). Repeating the latter Heck cross-coupling reactions under thermal heating at $130{ }^{\circ} \mathrm{C}$ in $\mathrm{DMF} /$ $\mathrm{TBAB} / \mathrm{Et}_{3} \mathrm{~N}$ for 90 min gave 100\% GC-conversion of the corresponding stilbenes 4, 17 and 21 in 92,97 and $82 \%$ isolated yields, respectively.

Further, arylation of acrylonitrile $\mathbf{2 b}$, ethyl acrylate $\mathbf{2 c}$ and with $n$-butyl acrylate $\mathbf{2 d}$ with aryl bromides 1, 5 and 6 proceeded smoothly under microwave irradiation at $160{ }^{\circ} \mathrm{C}$ to furnish, in all cases, the corresponding cinnamates 14-16, 18-20 and 22-24, respectively, in high isolated yields after a reaction time 4 7 min. The high conversion in the cross-coupling of the less active 4bromoanisole 6 with the olefins 2a-d (runs 9-12, Table 2) within 7 min of microwave irradiation gives a good support for the high catalytic activity of the Pd complex 3 . It was reported that strong bases such as $\mathrm{KOH}$ decompose $n$-butyl acrylate to give $n$-butanol and acrylic acid ${ }^{21}$ and hence was not used in this study.

Interestingly, the cross-coupling arylation process was highly regio- and stereoselective and provided only the thermodynamically more stable trans-isomer of stilbenes, cinnamonitriles and cinnamates 4, 14-24, where GC, GC-MS and ${ }^{1} \mathrm{H}$ NMR of the crude reaction mixture showed no evidence for other isomers. The stereochemistry of the double bond in the reaction products was easily established. For example, the protons around the double bond were found to resonate within the aromatic region with a coupling constant about $16 \mathrm{~Hz}$ attributed to related olefinic hydrogens. 
Table 2. Heck cross-coupling of aryl bromides with olefins under microwave irradiation

\begin{tabular}{|c|c|c|c|c|c|}
\hline & & $1,5,6$ & & $0.25 \mathrm{~mol} \%$ Cat 3 & 4, 14-24 \\
\hline \multirow{2}{*}{ Entry } & \multirow{2}{*}{$\mathrm{Y}$} & \multirow{2}{*}{$\mathrm{X}$} & \multirow{2}{*}{ Product } & \multicolumn{2}{|c|}{ MW heating ${ }^{\mathrm{a}, \mathrm{b}}$} \\
\hline & & & & time $(\min )$ & yield $\%$ \\
\hline 1 & $\mathrm{CH}_{3} \mathrm{CO}$ & $\mathrm{Ph}$ & 4 & 5 & $100(88)^{\mathrm{c}}$ \\
\hline 2 & $\mathrm{CH}_{3} \mathrm{CO}$ & $\mathrm{CN}$ & 14 & 5 & $100(93)$ \\
\hline 3 & $\mathrm{CH}_{3} \mathrm{CO}$ & $\mathrm{CO}_{2} \mathrm{Et}$ & 15 & 5 & $100(78)$ \\
\hline 4 & $\mathrm{CH}_{3} \mathrm{CO}$ & $\mathrm{CO}_{2} \mathrm{Bu}^{n}$ & 16 & 5 & $100(85)$ \\
\hline 5 & $\mathrm{NO}_{2}$ & $\mathrm{Ph}$ & 17 & 4 & $100(75)^{d}$ \\
\hline 6 & $\mathrm{NO}_{2}$ & $\mathrm{CN}$ & 18 & 4 & $100(86)$ \\
\hline 7 & $\mathrm{NO}_{2}$ & $\mathrm{CO}_{2} \mathrm{Et}$ & 19 & 4 & $100(95)$ \\
\hline 8 & $\mathrm{NO}_{2}$ & $\mathrm{CO}_{2} \mathrm{Bu}^{n}$ & 20 & 4 & $100(88)$ \\
\hline 9 & $\mathrm{OCH}_{3}$ & $\mathrm{Ph}$ & 21 & 7 & $100(87)^{\mathrm{e}}$ \\
\hline 10 & $\mathrm{OCH}_{3}$ & $\mathrm{CN}$ & 22 & 7 & $98(88)$ \\
\hline 11 & $\mathrm{OCH}_{3}$ & $\mathrm{CO}_{2} \mathrm{Et}$ & 23 & 7 & $95(70)$ \\
\hline 12 & $\mathrm{OCH}_{3}$ & $\mathrm{CO}_{2} \mathrm{Bu}^{n}$ & 24 & 7 & $90(81)$ \\
\hline
\end{tabular}

${ }^{\mathrm{a} C}$ Conditions: Aryl bromide: $1 \mathrm{mmol}$; olefin: $1.5 \mathrm{mmol}$; TBAB: $0.6 \mathrm{mmol}$; $\mathrm{Et}_{3} \mathrm{~N}: 3 \mathrm{mmol}$; DMF: $3 \mathrm{~mL}$, Pd-complex: $0.25 \mathrm{~mol} \%$ under microwave heating (250 Watt) at $160{ }^{\circ} \mathrm{C} .{ }^{b}$ Conversions were based on GC-analysis and the values in parentheses refer to the isolated yields. ${ }^{c}$ Repeating this reaction under thermal heating at reflux for 90 min gave full conversion with $92 \%$ isolated yield. ${ }^{d}$ Thermal heating for $90 \mathrm{~min}$ gave $97 \%$ isolated yield. ${ }^{e}$ Thermal heating for 90 min gave $82 \%$ isolated yield.

Next, the applicability of complex 3 in Heck cross-coupling reaction of further activated and deactivated aryl and pyridyl bromides 7-13 with styrene 2a were carried out under thermal heating as well as microwave irradiation conditions was investigated as described in Table 3. In all cases, styrene was arylated smoothly resulting in the formation of the corresponding stilbenes 25-29 and styrylpyridines 30, 31 in good to excellent isolated yields. As can be seen in Table 3, high chemoselectivity was observed in the case of 1-bromo-4-chlorobenzene (entry 2), where the more reactive bromine atom was replaced with styryl group to give 4-chlorostilbene $\mathbf{2 6}$ with $100 \%$ conversion under microwave irradiation. Similar cross coupling of 1-bromonaphthalene under the same conditions afforded the cross coupled product $\mathbf{2 8}$ in excellent isolated yield with full GC-conversion under both thermal as well as microwave irradiation (entry 4, Table 3). In addition, the Pd(II)-complex 3 was found to efficiently catalyze the coupling of 2-amino-5bromopyridine 12 and 2-amino-6-bromopyridine 13 to give the corresponding 5-styryl- and 6styrylpyridines $\mathbf{3 0}$ and 31, respectively, in good yields under thermal and microwave heating modes (entries 6 and 7, Table 3). 2-Amino-6-bromopyridine 12 consumed longer reaction time 
than 2-amino-5-bromopyridine 13 under both thermal- and MW-heating reflecting the high activity of 5-bromopyridine than 6-bromopyridine. In all cases, the products were established to have the trans-configuration of 1,2-disubstituted ethylenes. The other regioisomers; 1,1disubstituted ethylenes due to $\alpha$-arylation ${ }^{22}$ were not detected in the crude reaction products. In addition, a recent publication reported the partial or complete hydrogenation of the double bond when the reaction was carried out at high temperature, however we could not detect any hydrogenated product during this work. ${ }^{23}$

Aryl chlorides are cheaper and more easily available than bromides and iodides, but less reactive. Efficient catalyst systems for the Heck reactions of aryl chlorides have been extensively studied. ${ }^{24}$ Herein, the reactivity of the Pd-complex $3(0.25 \mathrm{~mol} \%)$ in the Heck coupling of activated aryl chlorides (4-chloroacetophenone 32 and 4-chloronitrobenzene 33) with styrene 2a was studied under thermal heating as well as microwave irradiation conditions as shown in Scheme 1. Under this condition, very good yields of 4-acetylstilbene 4 and 4-nitrostilbene 17 were obtained. It is noteworthy to mention here that the catalytic activity of the Pd-complex $\mathbf{3}$ is more efficient in the Heck coupling of aryl chlorides if compared with similar reactions using our previously reported analogous $\mathrm{Pd}(\mathrm{II})$-complexes. ${ }^{15}$

Table 3. Heck cross-coupling of aryl and pyridyl bromides with styrene

Entry

${ }^{\mathrm{a} C}$ Conditions: Aryl bromide: $1 \mathrm{mmol}$; styrene: $1.5 \mathrm{mmol}$;BAB: $0.6 \mathrm{mmol}$; $\mathrm{Et}_{3} \mathrm{~N}$ : $3 \mathrm{mmol}$; DMF: $3 \mathrm{~mL}$, Pd-complex: $0.25 \mathrm{~mol} \%$ under microwave heating $(250 \mathrm{Watt})$ at $160{ }^{\circ} \mathrm{C}$ and thermal 
heating at $130{ }^{\circ} \mathrm{C}$. ${ }^{\mathrm{b}} \mathrm{All}$ values refer to the isolated yields. ${ }^{\mathrm{c}}$ Conversions were based on GCanalysis and the values in parentheses refer to the isolated yields.

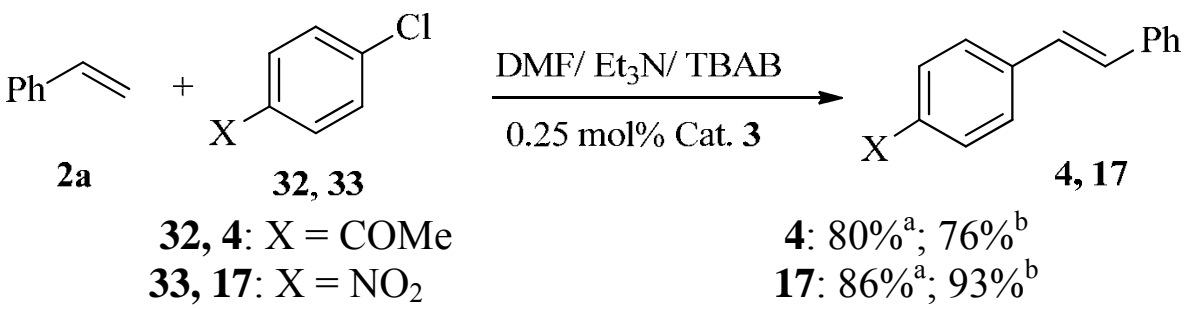

Scheme 1. Heck cross-coupling of activated aryl chlorides with styrene. Reaction conditions: ${ }^{\mathrm{a}}$ Thermal heating at $130{ }^{\circ} \mathrm{C}$ for $6 \mathrm{~h} .{ }^{\mathrm{b}}$ Microwave heating at $160{ }^{\circ} \mathrm{C}$ and $250 \mathrm{Watt}$ for $10 \mathrm{~min}$. All values refer to isolated yields.

\section{Heck cross-coupling of 2-acetyl-5-bromobenzofuran}

In the next section, we examined the catalytic activity of the $\mathrm{Pd}(\mathrm{II})$ complex 3 in the Heck crosscoupling reaction of 2-acetyl-5-bromobenzofuran 34 with styrene 2a under various reaction conditions as outlined in Table 4. The reaction was carried out in different solvent such as water, dimethylformamide and toluene using $\mathrm{Et}_{3} \mathrm{~N}$ and $\mathrm{KOH}$ as examples of organic and inorganic bases and TBAB as additive was used in order to achieve good yields. In this aspect, water/KOH/TBAB and water/Et ${ }_{3} \mathrm{~N} / \mathrm{TBAB}$ catalytic systems provided good results 91 and $95 \%$ GC-conversions, respectively, into $(E)$ - 2-acetyl-5-( $\beta$-styryl)benzofuran 35, (entries 1 and 2, Table 4). The use of DMF/ $\mathrm{Et}_{3} \mathrm{~N} / \mathrm{TBAB}$ as catalytic system (entry 5) was more efficient resulting in full conversion with excellent isolated yield (99\%) of the product 35 after $4 \mathrm{~h}$ of thermal heating at $130{ }^{\circ} \mathrm{C}$ using $0.25 \mathrm{~mol} \%$ of Pd-complex 3. This condition (DMF/Et ${ }_{3} \mathrm{~N} / \mathrm{TBAB}$ ) was repeated under microwave heating at $160{ }^{\circ} \mathrm{C}$ (250 Watt) for $20 \mathrm{~min}$ to obtain $100 \% \mathrm{GC}$ conversion ( $92 \%$ isolated yield) of 35 , and at room temperature (about $30{ }^{\circ} \mathrm{C}$ ) for $24 \mathrm{~h}$ with stirring to give no reaction at all based on GC-analysis with full recovering of the bromide 34. On the other hand, when the same reaction was carried out using DMF/KOH/TBAB catalytic system for $4 \mathrm{~h}$ of thermal heating it gave lower GC-conversion $(85 \%)$ than in the case of using $\mathrm{DMF} / \mathrm{Et}_{3} \mathrm{~N} / \mathrm{TBAB}$ (entry 4, Table 4). Toluene was found to be not appropriate for cross coupling of the bromide 34 with styrene $2 \mathrm{a}$ in either $\mathrm{KOH}$ or $\mathrm{Et}_{3} \mathrm{~N}$ as bases to give either nil or 4\% GCconversions, respectively (entries 7 and 8, Table 4).

The presence of TBAB is essential for carrying out Heck cross-coupling reactions ${ }^{19}$ as shown in Table 4 (entries 1, 2, 4 and 5) and its absence resulted in sharp decrease of the coupling product regardless the used solvent (water or DMF) in the reaction between 2-acetyl-5bromobenzofuran 34 and styrene under thermal heating (entries 3 and 6, Table 4). 
Table 4. Base and solvent effect on Heck coupling of 2-acetyl-5-bromobenzofuran 34 with styrene 2a

\begin{tabular}{|c|c|c|c|c|}
\hline \multirow[b]{2}{*}{ Entry } & $2 \mathbf{a}$ & 3 & \multicolumn{2}{|c|}{$\underset{\substack{0.25 \text { mol\% Cat. } 3 \\
\text { reflux }}}{\stackrel{\text { solvent/ base }}{\longrightarrow}}$} \\
\hline & Solvent & Base & $\begin{array}{l}\text { thermal } \\
\text { time }(\mathrm{h})\end{array}$ & $\begin{array}{l}\text { heating }^{\mathrm{a}, \mathrm{b}} \\
\text { yield } \%\end{array}$ \\
\hline 1 & $\mathrm{H}_{2} \mathrm{O} / \mathrm{TBAB}$ & $\mathrm{KOH}$ & 4 & $91(89)$ \\
\hline 2 & $\mathrm{H}_{2} \mathrm{O} / \mathrm{TBAB}$ & $\mathrm{Et}_{3} \mathrm{~N}$ & 4 & 95 \\
\hline 3 & $\mathrm{H}_{2} \mathrm{O}$ & $\mathrm{KOH}$ & 4 & 63 \\
\hline 4 & $\mathrm{DMF} / \mathrm{TBAB}$ & $\mathrm{KOH}$ & 4 & 85 \\
\hline 5 & $\mathrm{DMF} / \mathrm{TBAB}$ & $\mathrm{Et}_{3} \mathrm{~N}$ & 4 & $100(99)^{\mathrm{c}, \mathrm{d}}$ \\
\hline 6 & DMF & $\mathrm{Et}_{3} \mathrm{~N}$ & 12 & 30 \\
\hline 7 & Toluene & $\mathrm{KOH}$ & 4 & 0 \\
\hline 8 & Toluene & $\mathrm{Et}_{3} \mathrm{~N}$ & 4 & 4 \\
\hline
\end{tabular}

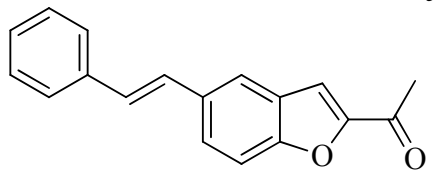

35

${ }^{a}$ Conditions: Bromide: $1 \mathrm{mmol}$; styrene: $1.5 \mathrm{mmol}$; TBAB: $0.6 \mathrm{mmol}$; base: $3 \mathrm{mmol}$; solvent: $3 \mathrm{~mL}$, Pd-complex 3: $0.25 \mathrm{~mol} \%$ at reflux condition for $4 \mathrm{~h} .{ }^{\mathrm{b}}$ Conversions were based on GCanalysis and the values in parenthesis refer to the isolated yields. ${ }^{c}$ Repeating this condition at r.t. for $24 \mathrm{~h}$ resulted in no reaction. ${ }^{\mathrm{d}}$ Repeating this condition under $\mathrm{MW}$ at $160{ }^{\circ} \mathrm{C}$ (250 Watt) resulted in $92 \%$ yield with full conversion after $20 \mathrm{~min}$.

Based on the foregoing results, vinylation of 2-acetyl-5-bromobenzofuran 34 with acrylic systems such as acrylonitrile $\mathbf{2 b}$, ethyl acrylate $\mathbf{2 c}$, $n$-butyl acrylate $\mathbf{2 d}$, tert-butyl acrylate $\mathbf{2 e}$ and methyl acrylate $\mathbf{2 f}$ under both microwave irradiation and thermal heating is illustrated in Table 5. For the synthesis of E-3-(2-acetylbenzofuran-5-yl)acrylonitrile 36 from the cross-coupling of 34 with $\mathbf{2 b}$, the reaction was conducted in $\mathrm{DMF} / \mathrm{Et}_{3} \mathrm{~N} / \mathrm{TBAB}$ as catalytic system using $0.25 \mathrm{~mol} \%$ of the Pd-complex 3. Full conversion was obtained after 3 hours of thermal heating (isolated yield $88 \%$ ) and after $20 \mathrm{~min}$ of microwave irradiation (isolated yields $88 \%$ ) of the benzofuranylacrylonitrile 36 (entry 1, Table 5). Under similar catalytic cross-coupling condition, 2-acetyl-5-bromobenzofuran 34 was vinylated with further acrylates 2c-f and the Heck coupling reaction was completed within 3-4 hours under thermal heating and after 20 min of microwave irradiation with high isolated yields $(>80 \%)$ of the corresponding 5-(benzofuranyl)acrylates 3740 (Table 5, entries 2, 3, 4, 6). The role of TBAB as an additive was crucial for the effective vinylation in the synthesis of the cross-coupled products 36-40, however in the absence of TBAB a dramatic effect appeared as no conversion at all after $16 \mathrm{~h}$ of thermal heating or $30 \mathrm{~min}$ of microwave irradiation during the coupling of tert-butyl acrylate $2 \mathbf{e}$ with 2-acetyl-5bromobenzofuran 34 (Table 5, entry 5). The same effect for absence of TBAB was encountered in the coupling of methyl acrylate $2 \mathrm{f}$ with 34 giving only $17 \%$ conversion after $16 \mathrm{~h}$ of thermal 
heating (entry 7, Table 5) reflecting the essential role of TBAB in such cross coupling reactions. The structures of the newly synthesized cross-coupled products 36-40 were established on the basis of their elemental and spectral analyses as described in the experimental section.

Table 5. Heck cross-coupling of 2-acetyl-5-bromobenzofuran 34 with acrylates 2 b-f

\begin{tabular}{|c|c|c|c|c|c|c|}
\hline & & & 34 & & & $36-40$ \\
\hline Entry & $\mathrm{R}$ & Product No. & $\begin{array}{l}\text { Thermal } \\
\text { time }(\mathrm{h})\end{array}$ & $\begin{array}{l}\text { eating }{ }^{\mathrm{a}, \mathrm{b}} \\
\text { yield } \%\end{array}$ & $\begin{array}{l}\text { MW he } \\
\text { time(min) }\end{array}$ & $\begin{array}{l}\text { yield } \% \\
\text { yang }\end{array}$ \\
\hline 1 & $\mathrm{CN}$ & 36 & 3 & $100(88)$ & 20 & $100(88)$ \\
\hline 2 & $\mathrm{CO}_{2} \mathrm{Et}$ & 37 & 3 & $100(91)$ & 20 & $100(81)$ \\
\hline 3 & $\mathrm{CO}_{2} \mathrm{Bu}^{n}$ & 38 & 3 & $100(80)$ & 20 & $100(91)$ \\
\hline 4 & $\mathrm{CO}_{2} \mathrm{Bu}^{t}$ & 39 & 4 & $100(86)$ & 20 & $100(95)$ \\
\hline 5 & $\mathrm{CO}_{2} \mathrm{Bu}^{t}$ & 39 & $16^{\mathrm{c}}$ & 0 & 30 & 0 \\
\hline 7 & $\mathrm{CO}_{2} \mathrm{Me}$ & 40 & 4 & $100(93)$ & n.d. & n.d. \\
\hline 8 & $\mathrm{CO}_{2} \mathrm{Me}$ & 40 & $16^{\mathrm{c}}$ & 17 & n.d. & n.d. \\
\hline
\end{tabular}

${ }^{a}$ Conditions: Bromide: 1 mmol; olefin: 1.5 mmol; TBAB: 0.6 mmol; Et ${ }_{3} \mathrm{~N}: 3$ mmol; DMF: 3 mL, Pd-complex: $0.25 \mathrm{~mol} \%$, microwave heating (250 Watt) at $160{ }^{\circ} \mathrm{C}$ and thermal heating at $130{ }^{\circ} \mathrm{C}$. ${ }^{\mathrm{b}}$ Conversions were based on $\mathrm{GC}$-analysis and the values in parentheses refer to the isolated yields. ${ }^{c}$ Without TBAB. n.d. = not done

In conclusion, the $\mathrm{Pd}(\mathrm{II})$-complex 3 was found to be efficient and highly active precatalyst for Mizoroki-Heck cross-coupling reactions of activated and deactivated aryl halides with styrene and acrylates under thermal heating as well as microwave irradiation conditions. Complex 3 was also highly active precatalyst when applied to the first vinylation reactions of 2acetyl-5-bromobenzofran. In all studied cases, $0.25 \mathrm{~mol} \%$ of the Pd-complex 3 were sufficient for full conversion within short reaction times.

\section{Experimental Section}

General. Melting points were determined in open glass capillaries with a Gallenkamp apparatus. The infrared spectra were recorded in potassium bromide disks on a Pye Unicam SP 3-300 and Shimaduz FTIR 8101 PC infrared spectrophotometer. NMR spectra were recorded with a Varian 
Mercury VXR-300 NMR spectrometer at $300 \mathrm{MHz}\left({ }^{1} \mathrm{H} \mathrm{NMR}\right)$ and at $75 \mathrm{MHz}\left({ }^{13} \mathrm{C} \mathrm{NMR}\right)$ using $\mathrm{CDCl}_{3}$ as solvent and internal standard $\left(\delta 7.27\right.$ and $77.36 \mathrm{ppm}$, for ${ }^{1} \mathrm{H} \mathrm{NMR}$ and ${ }^{13} \mathrm{C} \mathrm{NMR}$, respectively). Capillary GC analyses were performed with a Shimadzu GC-14A or GC-14B, a Shimadzu C-R6A integrator, and an HP 5 column ( $25 \mathrm{~m}$ length, $0.25 \mathrm{~mm}$ i.d., $0.25 \mu \mathrm{m}$ film) or recorded with an Agilent GC 6890N. Mass spectra (EI) were obtained at $70 \mathrm{eV}$ with a type Shimadzu GCMQP 1000 EX spectrometer. Analytical thin-layer chromatography was performed using pre-coated silica gel 60778 plates (Fluka), and the spots were visualized with UV light at $254 \mathrm{~nm}$. Fluka silica gel 60741 (70-230 mesh) was used for flash column chromatography. Microwave experiments were carried out using a CEM Discover Labmate $^{\mathrm{TM}}$ microwave apparatus (300 W with ChemDriver ${ }^{\mathrm{TM}}$ Software).

\section{Effect of concentration of Pd-complex 3 on Heck coupling of 4-bromoacetophenone with styrene in DMF under thermal heating}

A mixture of 4-bromoacetophenone 1 (199 mg, $1 \mathrm{mmol})$ and styrene 2a (156 mg, $1.5 \mathrm{mmol})$, TBAB (194 mg, $0.6 \mathrm{mmol}$ ), palladium complex 3 (4.59 mg, $1 \mathrm{~mol} \%$ ), TEA (303 mg, $3 \mathrm{mmol}$ ) and DMF $(3 \mathrm{~mL})$ was stirred at $130{ }^{\circ} \mathrm{C}$ under open air for $1.5 \mathrm{~h}$ to give 4 -acetylstilbene 4 . The same experiment was repeated using of palladium complex 3 in different mol\% e.g. $0.75,0.5$, $0.25,0.125,0.05,0.025,0.0125$ and $0.0 \mathrm{~mol} \%$ of 3 with respect to 4 -bromoacetophenone $\mathbf{1}$. The molar ratios of the reaction components were in all cases as follows; 4-bromoacetophenone, styrene, TBAB, TEA, DMF: 1 / 1.5 / 0.6 / 3 / 3 mL DMF.

Effect of base and solvent on Heck coupling of 4-bromoacetophenone with styrene under thermal heating

A mixture of 4-bromoacetophenone 1 (199 mg, $1 \mathrm{mmol})$ and styrene 2a (156 mg, $1.5 \mathrm{mmol})$, TBAB (194 mg, $0.6 \mathrm{mmol})$, Pd-complex 3 (1.14 mg, $0.25 \mathrm{~mol} \%$ ), and potassium hydroxide $(168 \mathrm{mg}, 3 \mathrm{mmol})$ in water $(3 \mathrm{~mL})$ was stirred at $130{ }^{\circ} \mathrm{C}$ under open air for $1.5 \mathrm{~h}$. After the reaction was almost complete (monitored by GC), to give 4-acetylstilbene 4 . The same experiment was repeated using different solvent and base. The molar ratios of the reaction components were in all cases as follows; 4-bromoacetophenone, styrene, TBAB, base, and solvent: $1 / 1.5 / 0.6 / 3 / 3 \mathrm{~mL}$. The yield \% versus different solvents and bases is outlined in Table 1.

\section{Heck vinylation of aryl bromides in DMF under microwave heating}

A mixture of the appropriate aryl bromides $\mathbf{1}, 5$ or $\mathbf{6}(1 \mathrm{mmol})$ and the appropriate olefins 2a-d (1.5 mmol), TBAB (0.6 mmol), Pd-complex 3 (0.25 mol\%), and $\mathrm{Et}_{3} \mathrm{~N}$ (303 mg, $3 \mathrm{mmol}$ ) in DMF $(3 \mathrm{~mL})$ was mixed in a process vial. The vial was capped properly, and the mixture was then heated under microwave irradiating conditions at $160{ }^{\circ} \mathrm{C}$ and 250 Watt for the appropriate reaction time as listed in Table 2 . After the reaction was almost complete (monitored by TLC), the reaction mixture was left to cool to room temperature. The reaction mixture was then extracted three times with EtOAc $(3 \times 20 \mathrm{~mL})$ and then the organic fractions were combined together, dried over $\mathrm{MgSO}_{4}$, filtered and then the solvent was removed under vacuum. The 
residue was then subjected to purification via flash column chromatography with petroleum $n$ hexane-EtOAc (10:1) as eluent to give the corresponding pure products 4 and 14-24.

(E)-4-Acetylstilbene (4). White crystals; mp 134-136 ${ }^{\circ} \mathrm{C}$ (Ref. ${ }^{25} \mathrm{mp} 134-136{ }^{\circ} \mathrm{C}$ ); ${ }^{1} \mathrm{H}$ NMR $\left(\mathrm{CDCl}_{3}\right) \delta 2.61\left(\mathrm{~s}, 3 \mathrm{H}, \mathrm{CH}_{3} \mathrm{CO}\right), 7.13(\mathrm{~d}, 1 \mathrm{H}, J=16.2 \mathrm{~Hz}), 7.24(\mathrm{~d}, 1 \mathrm{H}, J=16.2 \mathrm{~Hz}), 7.29-7.42$ $(\mathrm{m}, 3 \mathrm{H}), 7.55(\mathrm{~d}, 2 \mathrm{H}, J=7.5 \mathrm{~Hz}), 7.59(\mathrm{~d}, 2 \mathrm{H}, J=8.4 \mathrm{~Hz}), 7.96(\mathrm{~d}, 2 \mathrm{H}, J=8.1 \mathrm{~Hz})$; MS $\mathrm{m} / \mathrm{z}(\%)$ 222 (68.7, $\left.\mathrm{M}^{+}\right), 176$ (37.3), 151 (25.4), 115 (43.3), 91 (100), 75 (32.8), 56 (40.3).

(E)-4-Acetylcinnamonitrile (14). Buff crystals; mp $84-86{ }^{\circ} \mathrm{C}$ (Ref. ${ }^{26} \mathrm{mp}$ is not mentioned); ${ }^{1} \mathrm{H}$ $\operatorname{NMR}\left(\mathrm{CDCl}_{3}\right) \delta 2.56\left(\mathrm{~s}, 3 \mathrm{H}, \mathrm{CH}_{3} \mathrm{CO}\right), 5.97(\mathrm{~d}, 1 \mathrm{H}, J=16.8 \mathrm{~Hz}), 7.38(\mathrm{~d}, 1 \mathrm{H}, J=16.8 \mathrm{~Hz}), 7.51$ (d, $2 \mathrm{H}, J=8.1 \mathrm{~Hz}), 7.93$ (d, 2H, $J=8.1 \mathrm{~Hz}) ; \mathrm{MS} \mathrm{m} / \mathrm{z}(\%) 171\left(19, \mathrm{M}^{+}\right), 157$ (15.5), $115(100), 93$ (29.3), 73 (60.3), 55 (96.6).

(E) Ethyl 4-acetylcinnamate (15). White crystals; mp 40-42 ${ }^{\circ} \mathrm{C}$ (Ref. $\left.{ }^{27} \mathrm{mp} 42-44{ }^{\circ} \mathrm{C}\right) ;{ }^{1} \mathrm{H}$ NMR $\left(\mathrm{CDCl}_{3}\right) \delta 1.28(\mathrm{t}, 3 \mathrm{H}, J=7.2 \mathrm{~Hz}), 2.54\left(\mathrm{~s}, 3 \mathrm{H}, \mathrm{CH}_{3} \mathrm{CO}\right), 4.21(\mathrm{q}, 2 \mathrm{H}, J=7.2 \mathrm{~Hz}), 6.45(\mathrm{~d}, 1 \mathrm{H}, J$ $=15.9 \mathrm{~Hz}), 7.52(\mathrm{~d}, 2 \mathrm{H}, J=8.4 \mathrm{~Hz}), 7.62(\mathrm{~d}, 1 \mathrm{H}, J=15.9 \mathrm{~Hz}), 7.89(\mathrm{~d}, 2 \mathrm{H}, J=8.4 \mathrm{~Hz}) ; \mathrm{MS} \mathrm{m} / \mathrm{z}$ (\%) 218 (23.5, M+ ), 203 (68.6), 175 (34), 156 (26.1), 115 (100), 91 (34.6), 73 (66), 55 (99.3).

(E) $\boldsymbol{n}$-Butyl 4-acetylcinnamate (16). A colorless oil; ${ }^{28}{ }^{1} \mathrm{H} \mathrm{NMR}\left(\mathrm{CDCl}_{3}\right) \delta 0.88(\mathrm{t}, 3 \mathrm{H}, J=7.2$ $\mathrm{Hz}), 1.31-1.39$ (m, 2H), 1.58-1.63 (m, 2H), $2.50\left(\mathrm{~s}, 3 \mathrm{H}, \mathrm{CH}_{3} \mathrm{CO}\right), 4.13(\mathrm{t}, 2 \mathrm{H}, J=6.6 \mathrm{~Hz}), 6.43$ $(\mathrm{d}, 1 \mathrm{H}, J=16.2 \mathrm{~Hz}), 7.50(\mathrm{~d}, 2 \mathrm{H}, J=8.1 \mathrm{~Hz}), 7.58(\mathrm{~d}, 1 \mathrm{H}, J=16.2 \mathrm{~Hz}), 7.86(\mathrm{~d}, 2 \mathrm{H}, J=8.1$ $\mathrm{Hz}) ; \mathrm{MS} \mathrm{m} / \mathrm{z}(\%) 246$ (20.2, $\mathrm{M}^{+}$), 190 (60), 156 (24.3), 115 (100), 93 (32.5), 73 (70.1), 55 (97.8). (E)-4-Nitrostilbene (17). Yellow crystals; mp 160-162 ${ }^{\circ} \mathrm{C}$ (Ref. ${ }^{29} \mathrm{mp} \mathrm{161-162}{ }^{\circ} \mathrm{C}$ ); ${ }^{1} \mathrm{H}$ NMR $\left(\mathrm{CDCl}_{3}\right) \delta 7.15(\mathrm{~d}, 1 \mathrm{H}, J=16.2 \mathrm{~Hz}), 7.28(\mathrm{~d}, 1 \mathrm{H}, J=16.2 \mathrm{~Hz}), 7.34-7.44(\mathrm{~m}, 3 \mathrm{H}), 7.56(\mathrm{~d}, 2 \mathrm{H}, J$ $=8.1 \mathrm{~Hz}), 7.64(\mathrm{~d}, 2 \mathrm{H}, J=8.7 \mathrm{~Hz}), 8.22(\mathrm{~d}, 2 \mathrm{H}, J=8.7 \mathrm{~Hz}) ; \mathrm{MS} \mathrm{m} / \mathrm{z}(\%) 225\left(100, \mathrm{M}^{+}\right), 178$ (9.1), 153 (13.6), 119 (15.9), 65 (36.4), 50 (79.5).

(E)-4-Nitrocinnamonitrile (18). Brown crystals; mp 198-200 ${ }^{\circ} \mathrm{C}$ (Ref. $\left.{ }^{30} \mathrm{mp} \mathrm{198-199}{ }^{\circ} \mathrm{C}\right) ;{ }^{1} \mathrm{H}$ $\operatorname{NMR}\left(\mathrm{CDCl}_{3}\right) \delta 6.06(\mathrm{~d}, 1 \mathrm{H}, J=16.5 \mathrm{~Hz}), 7.47(\mathrm{~d}, 1 \mathrm{H}, J=16.5 \mathrm{~Hz}), 7.63(\mathrm{~d}, 2 \mathrm{H}, J=9 \mathrm{~Hz})$, 8.27 (d, 2H, $J=9 \mathrm{~Hz}) ; \mathrm{MS} \mathrm{m} / \mathrm{z}(\%) 174\left(35.3, \mathrm{M}^{+}\right.$), 130 (54.4), 102 (69.8), 76 (20.5), 55 (100).

(E) Ethyl 4-nitrocinnamate (19). Pale yellow crystals; mp 132-134 ${ }^{\circ} \mathrm{C}$ (Ref. ${ }^{27} \mathrm{mp} \mathrm{133-136}{ }^{\circ} \mathrm{C}$ ); ${ }^{1} \mathrm{H} \mathrm{NMR}\left(\mathrm{CDCl}_{3}\right) \delta 1.36(\mathrm{t}, 3 \mathrm{H}, J=7.2 \mathrm{~Hz}), 4.30(\mathrm{q}, 2 \mathrm{H}, J=7.2 \mathrm{~Hz}), 6.56(\mathrm{~d}, 1 \mathrm{H}, J=16.2 \mathrm{~Hz})$, $7.67(\mathrm{~d}, 2 \mathrm{H}, J=8.1 \mathrm{~Hz}), 7.71(\mathrm{~d}, 1 \mathrm{H}, J=16.2 \mathrm{~Hz}), 8.25(\mathrm{~d}, 2 \mathrm{H}, J=8.1 \mathrm{~Hz}) ; \mathrm{MS} m / z(\%) 221$ (33.3, $\left.\mathrm{M}^{+}\right), 176$ (100), 130 (63.2), 102 (64.9), 77 (22.8), 63 (54.4), 50 (19.3).

(E) n-Butyl 4-nitrocinnamate (20). Pale yellow crystals; mp 62-64 ${ }^{\circ} \mathrm{C}$ (Ref. ${ }^{31} \mathrm{mp} 63-65{ }^{\circ} \mathrm{C}$ ); ${ }^{1} \mathrm{H}$ NMR $\left(\mathrm{CDCl}_{3}\right) \delta 0.97(\mathrm{t}, 3 \mathrm{H}, J=6.9 \mathrm{~Hz}), 1.39-1.48(\mathrm{~m}, 2 \mathrm{H}), 1.66-1.73(\mathrm{~m}, 2 \mathrm{H}), 4.24(\mathrm{t}, 2 \mathrm{H}, J=$ $6.6 \mathrm{~Hz}), 6.56(\mathrm{~d}, 1 \mathrm{H}, J=15.9 \mathrm{~Hz}), 7.67(\mathrm{~d}, 2 \mathrm{H}, J=9 \mathrm{~Hz}), 7.71(\mathrm{~d}, 1 \mathrm{H}, J=15.6 \mathrm{~Hz}), 8.24(\mathrm{~d}, 2 \mathrm{H}$, $J=8.7 \mathrm{~Hz}$ ); MS m/z (\%) $249\left(5, \mathrm{M}^{+}\right), 194$ (30.2), 176 (60.6), 130 (24.7), 102 (75.2), 90 (32), 76 (53.6), 56 (100).

(E)-4-Methoxystilbene (21). Buff powder; mp 134-136 ${ }^{\circ} \mathrm{C}$ (Ref. $\left.{ }^{32} \mathrm{mp} 134-136{ }^{\circ} \mathrm{C}\right) ;{ }^{1} \mathrm{H}$ NMR $\left(\mathrm{CDCl}_{3}\right) \delta 3.85\left(\mathrm{~s}, 3 \mathrm{H}, \mathrm{OCH}_{3}\right), 6.93(\mathrm{~d}, 2 \mathrm{H}, J=8.7 \mathrm{~Hz}), 7.01(\mathrm{~d}, 1 \mathrm{H}, J=16.5 \mathrm{~Hz}), 7.11(\mathrm{~d}, 1 \mathrm{H}, J$ $=16.5 \mathrm{~Hz}), 7.24-7.30(\mathrm{~m}, 1 \mathrm{H}), 7.35-7.40(\mathrm{~m}, 2 \mathrm{H}), 7.48(\mathrm{~d}, 2 \mathrm{H}, J=8.7 \mathrm{~Hz}), 7.52(\mathrm{~d}, 2 \mathrm{H}, J=7.8$ $\mathrm{Hz}$ ); MS m/z (\%) 210 (100, $\left.\mathrm{M}^{+}\right), 195$ (68.3), 179 (61), 88 (43.9), 74 (64.3), 64 (46.3).

(E)-4-Methoxycinnamonitrile (22). Pale yellow powder; mp 60-62 ${ }^{\circ} \mathrm{C}\left(\operatorname{Ref}^{33} \mathrm{mp} 62-63{ }^{\circ} \mathrm{C}\right) ;{ }^{1} \mathrm{H}$ $\operatorname{NMR}\left(\mathrm{CDCl}_{3}\right) \delta 3.83\left(\mathrm{~s}, 3 \mathrm{H}, \mathrm{OCH}_{3}\right), 5.69(\mathrm{~d}, 1 \mathrm{H}, J=16.5 \mathrm{~Hz}), 6.90(\mathrm{~d}, 2 \mathrm{H}, J=8.1 \mathrm{~Hz}), 7.31(\mathrm{~d}$, 
1H, $J=16.5 \mathrm{~Hz}), 7.38(\mathrm{~d}, 1 \mathrm{H}, J=8.1 \mathrm{~Hz}) ; \mathrm{MS} \mathrm{m} / \mathrm{z}(\%) 159\left(100, \mathrm{M}^{+}\right), 145$ (63.3), 108 (49.2), 73 (59.4), 55(39).

(E) Ethyl 4-methoxycinnamate (23). Yellowish white crystals; mp $48-50{ }^{\circ} \mathrm{C}$ (Ref. ${ }^{31} \mathrm{mp} 48$ $\left.50{ }^{\circ} \mathrm{C}\right) ;{ }^{1} \mathrm{H}$ NMR $\left(\mathrm{CDCl}_{3}\right) \delta 1.32(\mathrm{t}, 3 \mathrm{H}, J=7.2 \mathrm{~Hz}), 3.80\left(\mathrm{~s}, 3 \mathrm{H}, \mathrm{OCH}_{3}\right), 4.24(\mathrm{q}, 2 \mathrm{H}, J=7.2$ $\mathrm{Hz}), 6.29$ (d, 1H, $J=15.9 \mathrm{~Hz}), 6.88$ (d, 2H, $J=7.8 \mathrm{~Hz}), 7.45$ (d, 2H, $J=8.1 \mathrm{~Hz}), 7.63$ (d, 1H, $J=$ $15.9 \mathrm{~Hz}) ; \mathrm{MS} \mathrm{m} / \mathrm{z}(\%) 206$ (75.1, M ), 183 (43.7), 149 (39.3), 108 (36.9), 71 (34.2), 57 (100).

(E) $n$-Butyl 4-methoxycinnamate (24). Colorless oil; ${ }^{28}{ }^{1} \mathrm{H}$ NMR $\left(\mathrm{CDCl}_{3}\right) \delta 0.95(\mathrm{t}, 3 \mathrm{H}, J=7.2$ $\mathrm{Hz}), 1.39-1.46(\mathrm{~m}, 2 \mathrm{H}), 1.65-1.70(\mathrm{~m}, 2 \mathrm{H}), 3.80\left(\mathrm{~s}, 3 \mathrm{H}, \mathrm{OCH}_{3}\right), 4.19(\mathrm{t}, 2 \mathrm{H}, J=6.9 \mathrm{~Hz}), 6.30(\mathrm{~d}$, $1 \mathrm{H}, J=15.9 \mathrm{~Hz}), 6.87(\mathrm{~d}, 2 \mathrm{H}, J=6.9 \mathrm{~Hz}), 7.44(\mathrm{~d}, 2 \mathrm{H}, J=6.9 \mathrm{~Hz}), 7.62(\mathrm{~d}, 1 \mathrm{H}, J=15.9 \mathrm{~Hz})$; MS m/z (\%) 234 (27.6, $\left.\mathrm{M}^{+}\right), 178$ (56.1), 156 (49.5), 108 (43.4), 75 (36.4), 57 (100).

\section{Heck coupling of styrene with aryl halides in DMF under thermal heating}

A mixture of the appropriate aryl halide 7-13, 32 and $33(1 \mathrm{mmol})$ and styrene $2 \mathrm{a}(1.5 \mathrm{mmol})$, TBAB (0.6 mmol), Pd-complex 3 (0.25 mol\%), and $\mathrm{Et}_{3} \mathrm{~N}$ (303 $\mathrm{mg}, 3 \mathrm{mmol}$ ) in DMF ( $3 \mathrm{~mL}$ ) was stirred at $130{ }^{\circ} \mathrm{C}$ under open air for the appropriate reaction time as listed in Table 3. After the reaction was almost complete (monitored by TLC), the reaction mixture was left to cool to room temperature. The reaction mixture was then extracted three times with EtOAc $(3 \times 20 \mathrm{~mL})$ and then the organic fractions were combined together, dried over $\mathrm{MgSO}_{4}$, filtered and then the solvent was removed under vacuum. The residue was then subjected to purification via flash column chromatography with petroleum $n$-hexane-EtOAc (10:1) as eluent to give the corresponding pure products 25-31, 4 and 17 , respectively.

\section{Heck coupling of styrene with aryl halides in DMF under microwave heating}

A mixture of the appropriate aryl halide 7-13, 32 and $33(1 \mathrm{mmol})$ and styrene $2 \mathrm{a}(1.5 \mathrm{mmol})$, TBAB (0.6 mmol), Pd(II)-complex 3 (0.25 mol\%), and TEA (303 mg, $3 \mathrm{mmol}$ ) in DMF (3 mL) was mixed in a process vial. The vial was capped properly, and the mixture was then heated under microwave irradiating conditions at $160{ }^{\circ} \mathrm{C}$ and 250 Watt for the appropriate reaction time as listed in Table 3. After the reaction was almost complete (monitored by TLC), the reaction mixture was left to cool to room temperature. The reaction mixture was then extracted three times with EtOAc $(3 \times 20 \mathrm{~mL})$ and then the organic fractions were combined together, dried over $\mathrm{MgSO}_{4}$, filtered and then the solvent was removed under vacuum. The residue was then subjected to purification via flash column chromatography with $n$-hexane-EtOAc (10:1) as eluent to give the corresponding pure products 25-31, 4 and 17, respectively.

(E)-4-Ethoxystilbene (25). Pale yellow crystals; mp 122-124 ${ }^{\circ} \mathrm{C}$ (Ref. $\left.{ }^{34} \mathrm{mp} 124-126{ }^{\circ} \mathrm{C}\right) ;{ }^{1} \mathrm{H}$ $\operatorname{NMR}\left(\mathrm{CDCl}_{3}\right) \delta 1.42(\mathrm{t}, 3 \mathrm{H}, J=7.2 \mathrm{~Hz}), 4.01(\mathrm{q}, 2 \mathrm{H}, J=7.2 \mathrm{~Hz}), 6.78(\mathrm{~d}, 2 \mathrm{H}, J=9 \mathrm{~Hz}), 6.86-$ $6.92(\mathrm{~m}, 1 \mathrm{H}), 6.98(\mathrm{~d}, 1 \mathrm{H}, J=16.5 \mathrm{~Hz}), 7.09(\mathrm{~d}, 1 \mathrm{H}, J=16.5 \mathrm{~Hz}), 7.38(\mathrm{~d}, 2 \mathrm{H}, J=9 \mathrm{~Hz}), 7.45-$ $7.48(\mathrm{~m}, 2 \mathrm{H}), 7.51$ (d, 2H, $J=6.9 \mathrm{~Hz}) ; \mathrm{MS} \mathrm{m} / \mathrm{z}(\%) 224\left(17.3, \mathrm{M}^{+}\right), 167$ (25.8), 149 (48.9), 129 (30.8), 104 (32.0), 91 (34.4), 77 (67.1), 57 (100).

(E)-4-Chlorostilbene (26). Buff crystals; mp 128-130 ${ }^{\circ} \mathrm{C}$ (Ref. ${ }^{32} \mathrm{mp} \mathrm{128-129}{ }^{\circ} \mathrm{C}$ ); ${ }^{1} \mathrm{H}$ NMR $\left(\mathrm{CDCl}_{3}\right) \delta 7.04(\mathrm{~d}, 1 \mathrm{H}, J=16.8 \mathrm{~Hz}), 7.11(\mathrm{~d}, 1 \mathrm{H}, J=16.8 \mathrm{~Hz}), 7.28-7.35(\mathrm{~m}, 3 \mathrm{H}), 7.38(\mathrm{~d}, 2 \mathrm{H}, J$ 
$=7.2 \mathrm{~Hz}), 7.45(\mathrm{~d}, 2 \mathrm{H}, J=8.4 \mathrm{~Hz}), 7.51(\mathrm{~d}, 2 \mathrm{H}, J=7.5 \mathrm{~Hz}) ; \mathrm{MS} \mathrm{m} / \mathrm{z}(\%) 214(100)\left(\mathrm{M}^{+}\right), 178$ (58.3), 115 (44.4), 91 (66.7), 75 (55.6), 50 (61.1).

(E)-3-Acetylstilbene (27). Colorless crystals; mp 78-80 ${ }^{\circ} \mathrm{C}\left(\operatorname{Ref}^{33} \mathrm{mp} \mathrm{79-80}{ }^{\circ} \mathrm{C}\right) ;{ }^{1} \mathrm{H} \mathrm{NMR}$ $\left(\mathrm{CDCl}_{3}\right) \delta 2.65\left(\mathrm{~s}, 3 \mathrm{H}, \mathrm{COCH}_{3}\right), 7.14(\mathrm{~d}, 1 \mathrm{H}, J=16.5 \mathrm{~Hz}), 7.21(\mathrm{~d}, 1 \mathrm{H}, J=16.5 \mathrm{~Hz}), 7.29-7.34$ $(\mathrm{m}, 1 \mathrm{H}), 7.35-7.41(\mathrm{~m}, 2 \mathrm{H}), 7.44-7.49(\mathrm{~m}, 1 \mathrm{H}), 7.54(\mathrm{~d}, 2 \mathrm{H}, J=7.5 \mathrm{~Hz}), 7.71(\mathrm{~d}, 1 \mathrm{H}, J=7.2$ $\mathrm{Hz}), 7.84$ (d, 1H, J=7.8 Hz), 8.11 (s, 1H); MS m/z (\%) 222 (58.3, $\left.\mathrm{M}^{+}\right), 179$ (45.8), 51 (100).

(E)-1-Styrylnaphthalene (28). Colorless oil; ${ }^{35}{ }^{1} \mathrm{H}$ NMR $\left(\mathrm{CDCl}_{3}\right) \delta 7.30(\mathrm{~d}, 1 \mathrm{H}, J=16.2 \mathrm{~Hz})$, $7.41-7.70(\mathrm{~m}, 6 \mathrm{H}), 7.74(\mathrm{~d}, 2 \mathrm{H}, J=7.8 \mathrm{~Hz}), 7.88(\mathrm{~d}, 1 \mathrm{H}, J=7.2 \mathrm{~Hz}), 7.93(\mathrm{~d}, 1 \mathrm{H}, J=8.4 \mathrm{~Hz})$, 7.99 -8.07 (m, 2H), $8.38(\mathrm{~d}, 1 \mathrm{H}, J=8.1 \mathrm{~Hz})$; MS m/z (\%) $230\left(100, \mathrm{M}^{+}\right), 229$ (94.3), 215 (24.3), 152 (43.5), 114 (29), 101 (22.4), 45 (32.8).

(E)-4-Benzoylstilbene (29). White crystals; mp 148-150 ${ }^{\circ} \mathrm{C}\left(\operatorname{Ref}^{36} \mathrm{mp} \mathrm{148-149}{ }^{\circ} \mathrm{C}\right)$; IR $(\mathrm{KBr})$ v $1644 \mathrm{~cm}^{-1}(\mathrm{C}=\mathrm{O}) ;{ }^{1} \mathrm{H}$ NMR $\left(\mathrm{CDCl}_{3}\right) \delta 7.17(\mathrm{~d}, 1 \mathrm{H}, J=16.2 \mathrm{~Hz}), 7.26(\mathrm{~d}, 1 \mathrm{H}, J=16.2 \mathrm{~Hz})$, $7.31-7.53(\mathrm{~m}, 6 \mathrm{H}), 7.56(\mathrm{~d}, 2 \mathrm{H}, J=7.5 \mathrm{~Hz}), 7.62(\mathrm{~d}, 2 \mathrm{H}, J=8.7 \mathrm{~Hz}), 7.80-7.85(\mathrm{~m}, 4 \mathrm{H}) ; \mathrm{MS} \mathrm{m} / \mathrm{z}$ (\%) 284 (65.1, $\mathrm{M}^{+}$), 207 (55.2), 178 (60.4), 105 (51), 77 (100).

(E)-2-Amino-6-styrylpyridine (30). Orange crystals; mp 106-108 ${ }^{\circ} \mathrm{C}\left(\operatorname{Ref}^{37} \mathrm{mp} \mathrm{106-108}{ }^{\circ} \mathrm{C}\right)$; ${ }^{1} \mathrm{H}$ NMR $\left(\mathrm{CDCl}_{3}\right) \delta 4.89\left(\mathrm{~s}, 2 \mathrm{H}, \mathrm{NH}_{2}\right), 6.36(\mathrm{~d}, 1 \mathrm{H}$, pyridine-3H, $J=8.1 \mathrm{~Hz}), 6.75(\mathrm{~d}, 1 \mathrm{H}$, pyridine-5H, $J=7.2 \mathrm{~Hz}), 7.03-7.11(\mathrm{~m}, 1 \mathrm{H}$, pyridine-4H), $7.17(\mathrm{~d}, 1 \mathrm{H}, J=16.2), 7.22-7.30(\mathrm{~m}$, 3H), $7.32(\mathrm{~d}, 2 \mathrm{H}, J=8.1 \mathrm{~Hz}), 7.38(\mathrm{~d}, 1 \mathrm{H}, J=16.2)$; MS m/z (\%) $196\left(12, \mathrm{M}^{+}\right), 181$ (23.2), 167 (27.2), 149 (52.7), 129 (36), 104 (31.5), 91 (55.4), 77 (75.8), 57 (100).

(E)-2-Amino-5-styrylpyridine (31). Yellow crystals; mp 200-202 ${ }^{\circ} \mathrm{C}\left(\operatorname{Ref}^{38} \mathrm{mp} 199-200{ }^{\circ} \mathrm{C}\right)$; ${ }^{1} \mathrm{H} \mathrm{NMR}\left(\mathrm{CDCl}_{3}\right) \delta 4.51\left(\mathrm{~s}, 2 \mathrm{H}, \mathrm{NH}_{2}\right), 6.53(\mathrm{~d}, 1 \mathrm{H}$, pyridine-3H, $J=8.4 \mathrm{~Hz}), 6.92(\mathrm{~d}, 1 \mathrm{H}, J=$ $16.2 \mathrm{~Hz}), 7.07$ (d, 1H, J = 16.2 Hz), 7.22-7.38 (m, 3H), 7.48 (d, 2H, J = 7.8 Hz), $7.68(\mathrm{~d}, 1 \mathrm{H}$, pyridine-4H, $J=8.7 \mathrm{~Hz}), 8.18\left(\mathrm{~s}, 1 \mathrm{H}\right.$, pyridine-6H); MS m/z (\%) $196\left(50, \mathrm{M}^{+}\right), 178$ (52.8), 139 (55.6), 115 (66.7), 93 (44.4), 69 (100), 57 (63.9).

Effect of base and solvent on Heck coupling of 2-acetyl-5-bromobenzofuran (34) with styrene under thermal heating

A mixture of 2-acetyl-5-bromobenzofuran $34(239 \mathrm{mg}, 1 \mathrm{mmol})$ and styrene 2a (156 $\mathrm{mg}$, $1.5 \mathrm{mmol}$ ), TBAB (194 mg, $0.6 \mathrm{mmol})$, Pd-complex 3 (1.14 mg, $0.25 \mathrm{~mol} \%$ ), and potassium hydroxide $(168 \mathrm{mg}, 3 \mathrm{mmol})$ in water $(3 \mathrm{~mL})$ was stirred at $130{ }^{\circ} \mathrm{C}$ under open air for $4 \mathrm{~h}$. After the reaction was almost complete (monitored by GC), to give 2-acetyl-5-( $\beta$-styryl)benzofuran 35. The same experiment was repeated using different solvent and base. The molar ratio of the reaction components were in all cases as follows; 2-acetyl-5-bromobenzofuran 34, styrene 2a, TBAB, base, solvent: $1 / 1.5 / 0.6 / 3 / 3 \mathrm{~mL}$. The yield \% versus different solvents and bases is outlined in Table 4.

Heck coupling of 2-acetyl-5-bromobenzofuran (34) with acrylates in DMF under thermal heating

A mixture of 2-acetyl-5-bromobenzofuran $34(239 \mathrm{mg}, 1 \mathrm{mmol})$ and appropriate acrylate $2 \mathbf{b}-\mathbf{f}$ (1.5 mmol), TBAB (0.6 mmol), complex 3 (0.25 mol\%), and $\mathrm{Et}_{3} \mathrm{~N}$ (303 $\left.\mathrm{mg}, 3 \mathrm{mmol}\right)$ in DMF $(3 \mathrm{~mL})$ was stirred at $130{ }^{\circ} \mathrm{C}$ under open air for the appropriate reaction time as listed in Table 5 . 
After the reaction was almost complete (monitored by TLC), the reaction mixture was left to cool to room temperature. The reaction mixture was then extracted three times with EtOAc $(3 \mathrm{x}$ $20 \mathrm{~mL}$ ) and then the organic fractions were combined together, dried over $\mathrm{MgSO}_{4}$, filtered and then the solvent was removed under vacuum. The residue was then subjected to purification via flash column chromatography with petroleum $n$-hexane-EtOAc $(7: 1)$ as eluent to give the corresponding pure products of 5-(benzofuranyl)acrylates 36-40.

\section{Heck coupling of 2-acetyl-5-bromobenzofuran (34) with acrylates in DMF under microwave heating}

A mixture of 2-acetyl-5-bromobenzofuran $34(239 \mathrm{mg}, 1 \mathrm{mmol})$ and appropriate olefin $\mathbf{2 b}-\mathbf{f}$ $(1.5 \mathrm{mmol})$, TBAB $(0.6 \mathrm{mmol})$, complex $3(0.25 \mathrm{~mol} \%)$, and $\mathrm{Et}_{3} \mathrm{~N}$ (303 $\left.\mathrm{mg}, 3 \mathrm{mmol}\right)$ in DMF $(3 \mathrm{~mL})$ was mixed in a process vial. The vial was capped properly, and the mixture was then heated under microwave irradiating conditions at $160{ }^{\circ} \mathrm{C}$ and 250 Watt for $20 \mathrm{~min}$. After the reaction was almost complete (monitored by TLC), the reaction mixture was left to cool to room temperature. The reaction mixture was then extracted three times with EtOAc $(3 \times 20 \mathrm{~mL})$ and then the organic fractions were combined together, dried over $\mathrm{MgSO}_{4}$, filtered and then the solvent was removed under vacuum. The residue was then subjected to purification via flash column chromatography with petroleum $n$-hexane-EtOAc (7:1) as eluent to give the corresponding pure products 5-(benzofuranyl)acrylates 36-40.

(E)-2-Acetyl-5-( $\beta$-styryl)benzofuran (35). Yellow powder; mp. 187-189 ${ }^{\circ} \mathrm{C} ; R_{f} 0.54$ (hexane : AcOEt 7:1); IR (KBr) v 3119 (w), 3024 (w), 1676 (s), 1297 (m), 1074 (s) cm ${ }^{-1}$; ${ }^{1} \mathrm{H}$ NMR $\left(\mathrm{CDCl}_{3}\right) \delta 2.63\left(\mathrm{~s}, 3 \mathrm{H}, \mathrm{CH}_{3} \mathrm{CO}\right), 7.11(\mathrm{~d}, 1 \mathrm{H}, J=16.5 \mathrm{~Hz}), 7.21(\mathrm{~d}, 1 \mathrm{H}, J=16.5 \mathrm{~Hz}), 7.25-7.31$ (m, 1H), 7.36-7.41 (m, 2H), 7.50-7.58 (m, 4H), $7.69(\mathrm{~d}, 1 \mathrm{H}, J=9 \mathrm{~Hz}), 7.80(\mathrm{~s}, 1 \mathrm{H}) ;{ }^{13} \mathrm{C}$ NMR (DEPT) $\left(\mathrm{CDCl}_{3}\right) \delta 26.4\left(1 \mathrm{CH}_{3}\right), 112.6,112.9,120.9,126.4,126.9,127.7,128.0,128.7,128.8$ (9CH), 127.5, 133.7, 137.1, 153.2, 155.3, 188.5 (6C); MS m/z (\%) $262\left(100, \mathrm{M}^{+}\right), 247$ (14.5), 191 (34.6), 95 (10.6), 63 (10.0), 51 (11.0). Anal. Calcd for $\mathrm{C}_{18} \mathrm{H}_{14} \mathrm{O}_{2}: \mathrm{C}, 82.42 ; \mathrm{H}, 5.38$. Found: C, $82.33 ; \mathrm{H}, 5.27 \%$.

(E)-3-(2-Acetylbenzofuran-5-yl)acrylonitrile (36). Yellow powder; mp. $122-124{ }^{\circ} \mathrm{C} ; R_{f} 0.57$ (hexane : AcOEt 7:1); IR (KBr) v $3113(\mathrm{w}), 3046(\mathrm{w}), 2205$ (m), $1684(\mathrm{~m}), 1552(\mathrm{~s}), 1276$ (s) $\mathrm{cm}^{-1} ;{ }^{1} \mathrm{H}$ NMR $\left(\mathrm{CDCl}_{3}\right) \delta 2.63\left(\mathrm{~s}, 3 \mathrm{H}, \mathrm{CH}_{3} \mathrm{CO}\right), 5.91(\mathrm{~d}, 1 \mathrm{H}, J=16.5 \mathrm{~Hz}), 7.51(\mathrm{~d}, 1 \mathrm{H}, J=16.5$ $\mathrm{Hz}), 7.51(\mathrm{~s}, 1 \mathrm{H}), 7.59-7.62(\mathrm{~m}, 2 \mathrm{H}), 7.80(\mathrm{~s}, 1 \mathrm{H}) ;{ }^{13} \mathrm{C} \mathrm{NMR}(\mathrm{DEPT})\left(\mathrm{CDCl}_{3}\right) \delta 26.5\left(1 \mathrm{CH}_{3}\right)$, 96.2, 112.5, 113.4, 123.1, 126.7, 150.0 (6CH), 118.0, 127.7, 129.8, 153.8, 156.7, 188.4 (6C); MS m/z (\%) 211 (72.9, $\left.\mathrm{M}^{+}\right), 196$ (100), 184 (22.0), 140 (44.1), 93 (16.9), 75 (33.9), 58 (64.4). Anal. Calcd for $\mathrm{C}_{13} \mathrm{H}_{9} \mathrm{NO}_{2}$ : C, 73.92; H, 4.29; N, 6.63. Found: C, 74.01; H, 4.16; N, 6.55\%.

(E) Ethyl 3-(2-acetylbenzofuran-5-yl)acrylate (37). Yellow powder; mp. 108-110 ${ }^{\circ} \mathrm{C} ; R_{f} 0.66$ (hexane : AcOEt 7:1); IR (KBr) v $3102(\mathrm{w}), 2927$ (w), $1710(\mathrm{~m}), 1671(\mathrm{~s}), 1635$ (m), $1283(\mathrm{~m})$, $1171(\mathrm{~s}) \mathrm{cm}^{-1} ;{ }^{1} \mathrm{H} \mathrm{NMR}\left(\mathrm{CDCl}_{3}\right) \delta 1.36\left(\mathrm{t}, 3 \mathrm{H}, \mathrm{CO}_{2} \mathrm{CH}_{2} \mathrm{CH}_{3}, J=7.2 \mathrm{~Hz}\right), 2.63\left(\mathrm{~s}, 3 \mathrm{H}, \mathrm{CH}_{3} \mathrm{CO}\right)$, 4.29 (q, $\left.2 \mathrm{H}, \mathrm{CO}_{2} \mathrm{CH}_{2} \mathrm{CH}_{3}, J=7.2 \mathrm{~Hz}\right), 6.46(\mathrm{~d}, 1 \mathrm{H}, J=16.2 \mathrm{~Hz}), 7.51(\mathrm{~s}, 1 \mathrm{H}), 7.59$ (d, $1 \mathrm{H}, J=9$ $\mathrm{Hz}), 7.68(\mathrm{~d}, 1 \mathrm{H}, J=8.7 \mathrm{~Hz}), 7.78(\mathrm{~d}, 1 \mathrm{H}, J=15.9 \mathrm{~Hz}), 7.85(\mathrm{~s}, 1 \mathrm{H}) ;{ }^{13} \mathrm{C}$ NMR (DEPT) $\left(\mathrm{CDCl}_{3}\right)$ $\delta 14.3,26.5\left(2 \mathrm{CH}_{3}\right), 60.6\left(1 \mathrm{CH}_{2}\right), 112.8,113.0,118.2,123.5,127.7,144.0(6 \mathrm{CH}), 127.6,130.7$, 
153.5, 156.4, 166.8, 188.4 (6C); MS m/z (\%) 258 (100, $\left.\mathrm{M}^{+}\right), 213$ (92.9), 186 (36.8), 171 (56.1), 115 (30.8), 63 (39.5). Anal. Calcd for $\mathrm{C}_{15} \mathrm{H}_{14} \mathrm{O}_{4}$ : C, 69.76; H, 5.46. Found: C, 69.65; H, 5.32\%.

(E) Butyl 3-(2-acetylbenzofuran-5-yl)acrylate (38). Yellow powder; mp. $76-78{ }^{\circ} \mathrm{C} ; R_{f} 0.57$ (hexane : AcOEt 7:1); IR (KBr) v 3097 (w), 2956 (w), 2872 (w), 1709 (m), 1680 (s), 1634 (m), $1284(\mathrm{~m}), 1170(\mathrm{~m}) \mathrm{cm}^{-1} ;{ }^{1} \mathrm{H} \mathrm{NMR}\left(\mathrm{CDCl}_{3}\right) \delta 0.98(\mathrm{t}, 3 \mathrm{H}, J=7.5 \mathrm{~Hz}), 1.42-1.49(\mathrm{~m}, 2 \mathrm{H}), 1.66-$ $1.73(\mathrm{~m}, 2 \mathrm{H}), 2.63\left(\mathrm{~s}, 3 \mathrm{H}, \mathrm{CH}_{3} \mathrm{CO}\right), 4.23(\mathrm{t}, 2 \mathrm{H}, J=6.6 \mathrm{~Hz}), 6.46(\mathrm{~d}, 1 \mathrm{H}, J=15.9 \mathrm{~Hz}), 7.51(\mathrm{~s}$, $1 \mathrm{H}), 7.59$ (d, 1H, $J=8.7 \mathrm{~Hz}), 7.68(\mathrm{~d}, 1 \mathrm{H}, J=8.7 \mathrm{~Hz}), 7.78(\mathrm{~d}, 1 \mathrm{H}, J=15.9 \mathrm{~Hz}), 7.85(\mathrm{~s}, 1 \mathrm{H})$; ${ }^{13} \mathrm{C}$ NMR (DEPT) $\left(\mathrm{CDCl}_{3}\right) \delta 13.7,26.5\left(2 \mathrm{CH}_{3}\right), 19.1,30.7,64.5\left(3 \mathrm{CH}_{2}\right), 112.8,113.0,118.2$, 123.5, 127.7, 143.9 (6CH), 127.6, 130.7, 153.5, 156.4, 166.9, 188.4 (6C); MS m/z (\%) 286 (25.4, $\mathrm{M}^{+}$), 230 (100), 213 (65.5), 171 (36.6), 115 (23.7), 56 (23.5). Anal. Calcd for $\mathrm{C}_{17} \mathrm{H}_{18} \mathrm{O}_{4}$ : C, 71.31; H, 6.34. Found: C, 71.26; H, 6.21\%.

(E) tert-Butyl 3-(2-acetylbenzofuran-5-yl)acrylate (39). White powder; mp. 150-152 ${ }^{\circ} \mathrm{C} ; R_{f}$ 0.58 (hexane : AcOEt 6:1); IR (KBr) v 3119 (w), 3004 (w), 2927 (w), 1706 (m), 1670 (m), 1631 (m), $1285(\mathrm{~m}), 1080(\mathrm{~m}) \mathrm{cm}^{-1} ;{ }^{1} \mathrm{H} \mathrm{NMR}\left(\mathrm{CDCl}_{3}\right) \delta 1.47\left(\mathrm{~s}, 9 \mathrm{H}, \mathrm{C}\left(\mathrm{CH}_{3}\right)_{3}\right), 2.55\left(\mathrm{~s}, 3 \mathrm{H}, \mathrm{CH}_{3} \mathrm{CO}\right)$, $6.31(\mathrm{~d}, 1 \mathrm{H}, J=15.9 \mathrm{~Hz}), 7.43(\mathrm{~s}, 1 \mathrm{H}), 7.50(\mathrm{~d}, 1 \mathrm{H}, J=8.7 \mathrm{~Hz}), 7.59$ (d, 1H, J=9 Hz), 7.61 (d, $1 \mathrm{H}, J=15.6 \mathrm{~Hz}), 7.76(\mathrm{~s}, 1 \mathrm{H}) ;{ }^{13} \mathrm{C}$ NMR $(\mathrm{DEPT})\left(\mathrm{CDCl}_{3}\right) \delta 26.5,28.2\left(2 \mathrm{CH}_{3}\right), 112.8,112.9$, $120.1,123.3,127.7,142.9$ (6CH), 80.6, 127.6, 131.0, 153.4, 156.3, 166.1, 188.4 (7C); MS m/z (\%) $286\left(8.3, \mathrm{M}^{+}\right), 230$ (100), 215 (91.4), 171 (6.5), 114 (8.3), 57 (13.7). Anal. Calcd for $\mathrm{C}_{17} \mathrm{H}_{18} \mathrm{O}_{4}$ : C, 71.31; H, 6.34. Found: C, 71.32; H, 6.18\%.

(E) Methyl 3-(2-acetylbenzofuran-5-yl)acrylate (40). Yellow powder; mp. 146-148 ${ }^{\circ} \mathrm{C} ; R_{f}$ 0.55 (hexane : AcOEt 6:1); IR (KBr) v 3108 (w), 2952 (w), 1706 (m), 1674 (s), 1631 (m), 1283 (s), $1143(\mathrm{~s}) \mathrm{cm}^{-1} ;{ }^{1} \mathrm{H} \mathrm{NMR}\left(\mathrm{CDCl}_{3}\right) \delta 2.55\left(\mathrm{~s}, 3 \mathrm{H}, \mathrm{CH}_{3} \mathrm{CO}\right), 3.75\left(\mathrm{~s}, 3 \mathrm{H}, \mathrm{CO}_{2} \mathrm{CH}_{3}\right), 6.38(\mathrm{~d}, 1 \mathrm{H}$, $J=15.9 \mathrm{~Hz}), 7.44(\mathrm{~s}, 1 \mathrm{H}), 7.51(\mathrm{~d}, 1 \mathrm{H}, J=8.7 \mathrm{~Hz}), 7.61(\mathrm{~d}, 1 \mathrm{H}, J=8.7 \mathrm{~Hz}), 7.72(\mathrm{~d}, 1 \mathrm{H}, J=$ $16.2 \mathrm{~Hz}), 7.77(\mathrm{~s}, 1 \mathrm{H}) ;{ }^{13} \mathrm{C}$ NMR $(\mathrm{DEPT})\left(\mathrm{CDCl}_{3}\right) \delta 26.5,51.7\left(2 \mathrm{CH}_{3}\right), 112.7,113.0,117.7$, 123.6, 127.7, 144.3 (6CH), 127.6, 130.7, 153.5, 156.4, 167.3, 188.4 (6C); MS m/z (\%) 244 (100, $\mathrm{M}^{+}$), 229 (46.0), 213 (62.1), 171 (27.5), 115 (17.9), 63 (10.0). Anal. Calcd for $\mathrm{C}_{14} \mathrm{H}_{12} \mathrm{O}_{4}$ : C, 68.85; H, 4.95. Found: C, 68.95; H, 4.90\%.

\section{Acknowledgements}

K.M.D and his student A.F.D are very thankful to Prof. Peter Metz (TU-Dresden) for giving them the chance to measure GC-analysis at his laboratory during the A.v.H. fellowships; JulySept. 2008. Also, K.M.D. is deeply indebted to A.v.H. Foundation for the gift of a CEM Discover Labmate ${ }^{\mathrm{TM}}$ microwave apparatus. 


\section{References}

1. (a) Malleron, J. L.; Fiaud, J. C.; Legros, J. Y. Handbook of Palladium-Catalysed Organic Reactions; Academic: San Diego, CA, 1997. (d) Dupont, J.; Pfeffer, M.; Spencer, J. Eur. J. Inorg. Chem. 2001, 1917. (b) M. Beller, A. Zapf: In Handbook of Organopalladium Chemistry for Organic Synthesis, Vol. 1 Negishi, E.-I., Ed., Wiley-Interscience: New York, 2002; pp 1209-1222. (c) Beller, M.; Bolm, C. Transition Metals for Organic Synthesis, 2nd Edn., Wiley-VCH: Weinheim, 2004. (d) de Meijere, A.; Diederich, F. Metal-Catalyzed Cross-Coupling Reactions, 2nd Edn., Wiley-VCH: Weinheim, 2004.

2. (a) Beller, M.; Zapf, A. Top. Catal. 2002, 19, 101. (b) Kantchev, E. A. B.; O'Brien, C. J.; Organ, M. G. Angew. Chem. Int. Ed. 2007, 46, 2768.

3. For Reviews see: (a) Heck, R. F. Acc. Chem. Res. 1979, 12, 146. (b) Cabri, W.; Candiani, I. Acc. Chem. Res. 1995, 28, 2. (c) Negishi, E.; Coperet, C.; Ma, S.; Liou, S.; Liu, F. Chem. Rev. 1996, 96, 365. (d) Crisp, G. T. Chem. Soc. Rev. 1998, 27, 427. (e) Beletskaya, J. P.; Cheprakov, A. V. Chem. Rev. 2000, 100, 3009. (f) Biffis, A.; Zecca, M.; Basato, M. J. Mol. Catal. A 2001, 173, 249. (g) Whitcombe, N. J.; Hii, K. K.; Gibson, S. E. Tetrahedron 2001, 57, 7449. (h) Dounay, A. B.; Overman, L. E. Chem. Rev. 2003, 103, 2945. (i) Alonso, F.; Beletskayab, I. P.; Yus, M. Tetrahedron 2005, 61, 11771.

4. (a) De Meijere, A.; Meyer, F. Angew. Chem., Int. Ed. Engl. 1994, 33, 2379. (b) Beleskaya, I. P.; Cheprakov, A.V. Chem. Rev. 2000, 100, 3009. (c) Blaser, H.-U. Chem. Commun. 2003, 293. (d) Blaser, H.-U.; Indolese, A.; Naud, F.; Nettekoven, U.; Schnyder, A. Adv. Synth. Catal. 2004, 346, 1583;

5. (a) Withcombe, N.; Hii-Mimi, K. K.; Gibson, S. Tetrahedron 2001, 57, 7449. (b) Botella, L.; Nájera, C. Tetrahedron 2004, 60, 5563. (c) Botella, L.; Nájera, C. J. Org. Chem. 2005, 70, 4360 .

6. Anastas, P. T.; Warner, J. C. Green Chemistry: Theory and Practice; Oxford University Press: New York, 1998; p 30.

7. (a) Anastas, P. T.; Williamson, T. C. Green Chemistry: Designing Chemistry for the Environment; ACS: Washington, DC, 1996. (b) Anastas, P. T.; Heine, P. T.; Williamson, T. C. Eds. Green Chemical Synthesis and Processes; ACS: Washington, DC, 2000. (c) Lancaster, M. Green Chemistry: An Introductory Text; RSC: Cambridge, 2002.

8. (a) Larhed, M.; Moberg, C.; Hallberg, A. Acc. Chem. Res. 2002, 35, 717. (b) Desai, B.; Kappe, C. O. In: Immobilized Catalysts Kirschning, A., Ed. Top. Curr. Chem. 2004, 242, 177. (c) Kappe, C. O. Angew. Chem. Int. Ed. 2004, 43, 6250. (d) Hoz, A.; Ortiz, A.D.; Moreno, A. Chem. Soc. Rev. 2005, 34, 164.

9. (a) Mingos, D. M. P.; Baghurst, D. R. Chem. Soc. Rev. 1991, 20, 1. (b) Strauss, C. R.; Trainor, R. W. Aust. J. Chem. 1995, 48, 1665. (c) Gabriel, C.; Gabriel, S.; Grant, E. H.; Halstead, B. S.; Mingos, D. M. P. Chem. Soc. Rev. 1998, 27, 213. 
10. (a) Elander, N.; Jones, J. R.; Lu, S. Y.; Stone-Elander, S. Chem. Soc. Rev. 2000, 29, 239. (b) Lidström, P.; Tierney, J.; Wathey, B.; Westman, J. Tetrahedron 2001, 57, 9225. (c) Larhed, M.; Hallberg, A. Drug Discovery Today 2001, 6, 406.

11. (a) Smith, R. A.; Chen, J.; Mader, M. M.; Muegge, I.; Moehler, U.; Katti, S.; Marrero, D.; Stirtan, W. G.; Weaver, D. R.; Xiao, H.; Carley, W. Bioorg. Med. Chem. Lett. 2002, 12, 2875. (b) Hayakawa, I.; Shioya, R.; Agatsuma, T.; Furukawa, H.; Sugano, Y. Bioorg. Med. Chem. Lett. 2004, 14, 3411. (c) Cowart, M.; Faghih, R.; Curtis, M. P.; Gfesser, G. A.; Bennani, Y. L.; Black, L. A.; Pan, L.; Marsh, K. C.; Sullivan, J. P.; Esbenshade, T. A.; Fox, G. B.; Hancock, A. A. J. Med. Chem. 2005, 48, 38. (d) Hall, A.; Billinton, A.; Brown, S. H.; Clayton, N. M.; Chowdhury, A.; Giblin, G. M. P.; Goldsmith, P.; Hayhow, T. G.; Hurst, D. N.; Kilford, I. R.; Naylor, A.; Passingham, B.; Winyard, L. Bioorg. Med. Chem. Lett. 2008, $18,3392$.

12. (a) Dawood, K. M.; Abdel-Gawad, H.; Ragab, E. A.; Ellithy, M.; Mohamed, H. A. Bioorg. Med. Chem. 2006, 14, 3672; (b) Dawood, K. M.; Abdel-Gawad, H.; Ellithey, M.; Mohamed, H.A.; Hegazi, B. Arch. Pharm. Chem. Life Sci. 2006, 339, 133; (c) Abdel-Aziz, H. A.; Mekawey, A. A. I.; Dawood, K. M. Eur J. Med. Chem. 2009, 44, 3637.

13. (a) Halabalaki, M.; Aligiannis, N.; Papoutsi, Z.; Mitakou, S.; Moutsatsou, P.; Sekeris, C.; Skaltsounis, A. J. Nat. Prod. 2000, 63, 1672; (b) Apers, S.; Paper, D.; Bürgermeister, J.; Baronikova, S.; Dyck, S.V.; Lemie're, G.; Vlietinck, A.; Pieters, L. J. Nat. Prod. 2002, 65, 718; (c) Stevenson, P. C.; Simmonds, M. S. J.; Yule, M. A.; Veitch, N. C.; Kite, G. C.; Irwin, D.; Legg, M. Phytochemistry 2003, 63, 41.

14. (a) Akgul, Y. Y.; Anil, H. Phytochemistry 2003, 63, 939; (b) Ali, Z.; Tanaka, T.; Iliya, I.; Iinuma, M.; Furusawa, M.; Ito, T.; Nakaya, K.-i.; Murata, J.; Darnaedi, D. J. Nat. Prod. 2003, 66, 558; (c) Kokialakis, N.; Magiatis, P.; Mitaku, S.; Pratsinis, H.; Tillequin, F. Planta Med. 2003, 69, 566; (d) Aslam, S. N.; Stevenson, P. C.; Phythian, S. J.; Veitch, N. C.; Hall, D. R. Tetrahedron 2006, 62, 4214.

15. (a) Dawood, K. M.; Kirschning, A. Tetrahedron 2005, 61, 12121; (b) Dawood, K. M. Tetrahedron 2007, 63, 9642; (c) Dawood, K. M.; Fayed, M. S.; Elkhalea, M. M. Arkivoc 2009 (xiii), 324; (d) Dawood, K. M.; Eldeftar, M. M. Synthesis, 2010, 1030;

16. (a) Solodenko, W.; Brochwitz, C.; Wartchow, R.; Hashem, Md. A.; Vaultier, M.; Dawood, K. M.; Kirschning, A. Mol. Div. 2005, 9, 333; (b) Dawood, K. M.; Solodenko, W.; Kirschning, A. Arkivoc 2007 (v), 104.

17. Darweesh, A. F.; Shaaban, M. R.; Farag, A. F.; Metz, P.; Dawood, K. M. Synthesis, 2010, accepted for publication.

18. De Vries, A. H. M.; Mulders, J. M. C. A.; Mommers, J. H. M.; Henderickx, H. J. W.; de Vries, J. G. Org. Lett., 2003, 5, 3285.

19. (a) Jeffery, T. Adv. Met. Org. Chem. 1996, 153; (b) Zapf, A.; Beller, M. Chem. Eur. J. 2001, 7, 2908; (c) Reetz, M. T.; Westermann, E. Angew. Chem. Int. Ed. 2000, 39, 165.

20. Farina, V. Adv. Synth. Catal. 2004, 346, 1553.

21. Sud, A.; Deshpande, R. M.; Chaudhari, R. V. J. Mol. Catal. A: Chem. 2007, 270, 144. 
22. (a) Gruendemann, S.; Albrecht, M.; Loch, J. A.; Faller, J. W.; Crabtree, R. H. Organometallics 2001, 20, 5485; (b) Loch, J. A.; Albrecht, M. ; Peris, E. ; Mata, J.; Faller, J. W. ; Crabtree, R. H. Organometallics 2002, 21, 700.

23. Malik, I.; Hussain, M.; Ali, A.; Toguem, S.-M. T.; Basha, F. Z.; Fischer, C.; Langer, P. Tetrahedron 2010, 66, 1637.

24. (a) Schnyder, A.; Aemmer, J.; Indolese, A. F.; Pittelkow, U.; Studer, M. Adv. Synth. Catal. 2002, 344, 495. (b) Diez-Barra, E.; Guerra, J.; Hornillos, V.; Merino, S.; Tejeda, J. Organometallics 2003, 22, 4610. (c) Consorti, C. S.; Zanini, M. L.; Leal, S.; Ebeling, G.; Dupont, J. Org. Lett. 2003, 5, 983; (d) Consorti, C. S.; Ebeling, G.; Flores, F. R.; Rominger, F.; Dupont, J. Adv. Synth. Catal. 2004, 346, 617. (e) Yang, D.; Chen, Y.-C.; Zhu, N.-Y. Org. Lett. 2004, 6, 1577. (f) Prockl, S. S.; Kleist, W.; Gruber, M. A.; Kohler, K. Angew. Chem., Int. Ed. 2004, 43, 1881. (g) Frey, G. D.; Schutz, J.; Herdtweck, E.; Herrmann, W. A. Organometallics 2005, 24, 4416; (h) Prockl, S.; Kleist, W.; Kohler, K. Tetrahedron 2005, 61, 9855.

25. Kantam, M. L. Tetrahedron 2007, 63, 8002.

26. Pathak, D. D.; Maheswaran, H.; Prasanth, K. L.; Kantam, M. L. Synlett 2007, 5, 757.

27. Mu, B. Tetrahedron 2007, 63, 11475.

28. Wang, R.; Twamley, B.; Shreeve, J. M. J. Org. Chem. 2006, 71, 426.

29. Suzuki, T. J. Am. Chem. Soc. 2005, 127, 11720.

30. Cai, M. Z. Chin. Chem. Lett. 2005, 16, 449.

31. Li, J. -H. Eur. J. Org. Chem. 2006, 22, 5099.

32. Aggarwal, V. K. J. Am. Chem. Soc. 2003, 125, 6034.

33. Gokel, G. W. Tetrahedron Lett. 1976, 39, 3495.

34. Heynekamp, J. J. J. Med. Chem. 2006, 49, 7182.

35. Alacid, E. J. Org. Chem. 2008, 73, 2315.

36. Listvan, V. N. Zh. Obshchei Khim. 1980, 50, 1523.

37. Honma, Y.; Hanamoto, K.; Hashiyama, T.; Sekine, Y.; Takeda, M.; Ono, Y.; Tsuzuraharat, K. J. Med. Chem.1984, 27, 125.

38. Bumagin, N. A.; Bykov, V. V.; Sukhomlinova, L. I.; Tolstaya, T. P.; Beletskaya, I. P. J. Organomet. Chem. 1995, 486, 259. 